\title{
NOTES ON PENTHESILEA: THE MARKS OF A PAST OF FEMALE HEROISM
}

\section{Samantha da Silva Diefenthaeler (a)}

(a) Universitat Pompeu Fabra. Barcelona, Spain. Email: samanthadief[at]gmail.com

\begin{abstract}
The goal of this paper is to construct an image map that will allow us to understand archetypes characteristics that accompany heroic representations of women in cinema. We will begin with the myth of Penthesilea, an Amazon queen whose tragic loss of feminine power will then guide us in the search for new archetypal deflections. We believe the archetype of Penthesilea signifies new leak points in representation of power as connected to the feminine. To prove that will be one of the main goals of this paper. We insist on highlighting that the images associated with the description of this character are allied to a structure linked with a kind of force and power commonly re lated to the male. Penthesilea bears the mark of an essentially solar/diurnal heroism, in which love will configure as an additional item that makes the characters confront each other violently. The result of this analysis will be a visual trajectory from a moment in the past that connects to contemporary representations of feminine heroism.
\end{abstract}

Keywords

Genre; Penthesilea; Female Power; Hero's Body; Cinema; Mythology; Imaginary; Ascensional Heroism; Femininity; Contemporary Cinema

This work is licensed under a Creative Commons «Attribution» 4.0 International License. 


\section{ЗАМЕТКИ О ПЕНТЕСИЛЕИ: СЛЕДЫ ЖЕНСКОГО ГЕРОИЗМА ПРОШЛОГО}

\section{Дифенталер Саманта да Силва (a)}

(a) Университет Помпеу Фабра. Барселона, Испания. Email: samanthadief[at]gmail.com

\section{Аннотация}

Целью данной работы является построение имагинативной карты, которая бы позволила нам понять особенности архетипов, сопровождающих героические образы женщин в кинематографе. Автор начинает с мифа об амазонской королеве Пентесилее, чья трагическая потеря женской силы позволяет рассмотреть и другие архетипические отклонения от нормы. Автор полагает, что архетип Пентесилеи знаменует собой новую форму репрезентации силы как части фемининного образа. Рассмотрение данного вопроса является одной из главных целей работы. Автор отмечает, что образы, связанные с описанием этого персонажа, тесно переплетены с коннотациями силы и власти, обычно понимаемыми как чисто мужские. Пентесилея несет на себе отпечаток по сути солнечного/ дневного героизма, в котором любовь будет фигурировать как дополнительный элемент, заставляющий персонажей яростно противопоставлять себя друг другу. Результатом авторского анализа станет создание визуальной траектории, позволяющей соединить современные изображения женского героизма с аналогичными явлениями в прошлом.

\section{Ключевые слова}

Жанр; Пентесилея; Женская сила; Героическое тело; Кинематограф; Мифология; Воображаемое; Восходящий героизм; Женственность; Современное кино

Это произведение доступно по лицензии Creative Commons «Attribution» («Атрибуция») 4.0 Всемирная 


\section{FORGOTTEN PAST}

In our search for pictorial representations of the Victories of Achilles, we come across an amphora ${ }^{1}$ which stands out for its particular features. As is usual for these pieces, we behold a hero in the midst of battle. However, its peculiarity relies on his adversary: a female figure holding arms in her hands. The woman is obviously represented as defeated, and Achilles is about to slay her. This representative scene arises an infinite number of possibilities, although its explicit denotation devolves on the confrontation of a woman with the great Achilles. The message is straight - even though the hero and the heroine are confronting themselves without any differences, with garbs and arms that turn them into equals, the prostration before the male forces inequality of power between both figures. But in the end, who is this woman?

The figure, Penthesilea ${ }^{2}$, the great queen of the Amazon women, is heading towards Troy in order to die at the hands of Achilles, whose event will demoralize her female warriors. Her secondary role is marked by her devaluation in literature. Homer never mentioned her in his works, and it Virgil to do so for the first time ${ }^{3}$, albeit briefly, in the Aeneid highlighting her distinctive courage and virginity, establishing analogies between her features and fire, an element worthy of the greatest of heroes. Among the possible readings of this image and its marked absence in literature we set our point of departure. We perceive a lack of importance in heroism when featuring women. Weak, although present, we pause at this spark of history marked by its lacking prominence.

If Homer and Virgil overlooked in the description of the path towards this war, Quintus of Smyrna saved her from this limbo by reproducing her story to detail in Posthomerica. When observing the typification of the great female warrior Penthesilea in this poem, we are facing the tragic sense of its glorious fate. Daughter of the mighty Ares and the

1 Achilles slaying Penthesilea, Athenian black-figure amphora C6th B.C, British Museum. COMPASS Image Caption: Wine jar, made in Athens about 540-530 BC 1836,0224.127, AN34520 001. Creative Commons Attribution-NonCommercial-ShareAlike 4.0 International (CC BY-NC-SA 4.0) license.

2 According to the Diccionario de Mitologia Universal. Tomo 2 (1991): PENTESILEA. Queen of the Amazons, successor of Orithia, came to the aid of Troja, and died at the hands of Achilles, after having performed prodigies of courage. Her death was very unfortunate for the Amazons, who, dying from this misfortune, did not do anything anymore. He didn't even refer to it. Homer, nothing talks about this princess. Virgil places her in the distinguished place among the warriors who came to the aid of Troy. (p.483)

3 The meeting between Penthesilea and Achilles was also described in the epic cycle Aethipis by Arctinues, but it is lost.

4 Virgili, 2005, p.33: "Penthesilea in fury leads the crescent-shielded ranks of Amazons and blazes amid her thousands; a golden belt she binds below her naked breast, and, as a warrior queen, dares battle, a maid clashing with men." 
queen of the Amazon women, wretched after her unintentionally murdering her sister ${ }^{1}$, she arrives at the war of Troy willing for redemption. An agile solar woman, a strong warrior, gripping her horse with her arms, is staining her body with the blood of her enemies and inspiring other Trojan women to go to battle ${ }^{2}$. She is Penthesilea, a heroine in her failure, her pain and her woeful fate.

As a consequence, the power of her heroism, even though having a secondary role, is not overshadowed de facto. From there, we turn our attention to this mythography with the aim of validating its representative recurrence, its peculiar feature. We perceive from this image a certain tendency that questions the association of female power with a nocturnal passiveness, whereas manliness remains, systematically, attached to the opposite active and the diurnal. Against this general inclination we have tried to detect the constant problems of this pattern. We believe the archetype of Penthesilea signifies new leak points in representation of power as connected to the feminine. To prove that will be one of the main goals of this paper. In this way we will observe the images cited throughout this essay, in accordance with the critical thought of "re-vision" proposed by Adrienne Rich, of "seeing differently, of displacing the critical emphasis of the images of women" (1979, p. 35).

Therefore, we summarize our starting point with a simple question: Is it possible to establish the ancient myth of Penthesilea as a break in the representation of the heroic feminine power? If so, its reappearances could be informing on the destiny or fate of the female actualization. In that sense, we could emphasise the association of the feminine to the nomadic thinking as proposed by Braidotti. That is, we don't take on any identity as permanent and we see the sexual difference as "providing shifting locations for multiple female feminist embodied voices" (Braidotti 2000 , p. 205). Hence, we recognize that the feminine bears no immediate, not even direct, relationship with real life of women. At the same time, we perceive tension among the images and representations of women as envisioned by men - being the mythology of Penthesilea and its respective historical mutations a possible point of analysis of these relationships.

1 De Esmirna, 2004, p. 63: "her own sister's death, for whom ever her sorrows waxed, Hippolyte, whom she had struck dead with her mighty spear, not of her will - 'twas at a stag she hurled. So came she to the far-famed land of Troy."

2 De Esmirna, 2004, p.84: "Nay, wherein have we been dowered of God more niggardly than men? Then let us shrink not from the fray see ye not yonder a woman far excelling men in the grapple of fight? 


\section{LIVING BETWEEN THE WORLDS}

We insist on highlighting that the images associated with the description of this character are allied to a structure linked with a kind of force and power commonly related to the male. In this manner, both in the poem as well as in the image of the artefact mentioned earlier, Penthesilea's force equals that of a hero insisting on fighting fear of immobility. From that it becomes evident for us, within the versions that we are dealing with, that a descriptive tendency associating war to solar weapons is connected to a diurnal system. Achilles will not allow the plenitude of her victory, so that in the Posthomerica, the hero stands out for Penthesilea's madness for taking up a space which does not belong to her, reinforcing the idea that the battlefield is not a place to be taken up by women ${ }^{1}$. Which is the punishment for this warrior who invades a diurnal system marked by the masculine? At the end of it, the life of this warrior will be interrupted once again by Achilles' spear, who, upon slaying her, will fall in love beholding the beauty of this heroine ${ }^{2}$.

At this point, we believe it is fundamental to add some considerations of the sociologist Pierre Bourdieu in relation to the symbolic violence of love. The author focuses on the nature of the feeling of love, questioning whether falling in love is nothing more than the "suspension of symbolic violence" (Bourdieu, 2009, p.133), or whether it is rather its supreme form, its most finished expression. On the other hand, for the author, falling in love is preached as the result of a kind of "accepted domination, unknown as such and practically recognized, in passion, happy or unhappy" (ibid.). Thus, we perceive that there is a need for domination that configures love as a takeover, which ultimately reveals an intrinsic lack that seeks recognition in the other. Bourdieu also stresses that achieving sublime love consists in abdicating the need for this symbolic domination.

It is however fundamental to understand the concepts of nocturnal and diurnal employed earlier. These systems support an anthropological trajectory, "the statement in order for the symbolism to appear" (Durand 2000, p. 109), connected by a symbolic imaginary.

According to Durand, the imaginary must be conceived as a configuration that results from an eternal vital struggle of man with his inevitable fate, that is death. For the author, both image systems, diurnal

1 Esmirna, 2004, p.93: "To thee, O Evil-Starred! Nay, but it was the darkness-shrouded Fates and thine own folly of soul that pricked thee on to leave the works of women, and to fare to war, from which strong men shrink shuddering back.

2 Esmirna, 2004, p.94: "Now from her head he plucked the helmet splendour-flashing like the beams of the great sun, or Zeus' own glory-light. Then, there as fallen in dust and blood she lay, rose, like the breaking of the dawn, to view "neath dainty-pencilled brows a lovely face, lovely in death." 
and nocturnal -corresponding to the solar and the lunar respectively,incorporate the imaginary as "essence of spirit, (...) an effort of self in order to raise the hope of living forward and against the aim of death" (Durand, 2012, p. 432). This separation in two systems is didactic - every time that they are connected, they constitute a dyad. It is essential to emphasise that for Durand, the specific division between the masculine and the feminine, as employed on image systems, is a pathological symptom of historical domination of one system over the other. That is, a man does not have to be virile, diurnal thought, and a woman, the mystical, nocturnal. In the author's words: "every imaginary is articulated through inevitably plural structures, though limited to three types gravitating around the matrix schemes of the (heroic) 'separating', of the (mystical) 'including' and the (scattering) 'dramatizing' - expanding the images of a narrative in time - (Durand, 2000, p. 57-58.). Meanwhile, the symbolic diurnal has constants of misogyny, as a consequence of a historical imposition which tends to value masculine power over the feminine power. In short, the "diurnal [system] of the image (...) is defined, in a general, as a system of antithesis" (Durand, 2012, p. 67). At the same time, due to this masculine domination, the symbolic representations of the diurnal system, bipolar in essence, disregard the feminine, which is articulated as one of the dangers of the antiphrasis system, assigning different qualities to different symbolic objects. In essence we could summarize it as a system of the mystical, which symbolically accepts cycles and sexuality, a leaking line for the neurosis implemented from the diurnal system.

It is fundamental to insist on this distortion on the representations of the diurnal power, "an imaginative regime of the great patriarchal civilizations" (Bou, 2006, p. 67), which constantly associate the woman with one of the threats of any hero, "that is, sexuality or frivolous dispersion" (Durand, 1993, p. 207). From that reflection, we turn again to the archetype of Penthesilea, mortal woman who, according to the representative constants of the myth, is related to swiftness because of her mastery over her horse, her combat power is associated to her ability with the spear and the strength of her reign, features which allow for the establishment on this archetype, woman warrior, a type figurative oxymoron. We mean that through understanding these symbols according to the archaeology suggested by Durand, we perceive that they are essentially diurnal and find themselves constantly linked to the great solar hero. Indeed, the horse, the cedar and the gladius are legitimate weapons used to stop the passing of time. Therefore, we can assert that Penthesilea inhabits this system, negating the historical essence which wants to bond her to a mystical feminine power. Her trajectory teaches as well about the censorship 
of the genre which insists in differentiating the features of men and women.

We emphasize that within the figurative representations of the myth there is a constant punishment to Penthesilea, restrained by the legitimate solar hero. In such a manner, we validate from the representative constants related to the mythical image, that the "legitimate" diurnal agent arises as a figurative perseverance that will cease the continuity of this abhorrence of Penthesilea, the diurnal infiltrating the wrong body, inscribed in the body of a woman. Precisely, it is possible to grasp in this character the intervention of a device that disguises the action of a binary power: her strength demonstrates a capacity to confront the great hero, but, at the same time, her body, qualified as feminine, sentences her to live defeat once and again. Thus, the limits for the intervention of the feminine in a space marked by the masculine, we witness the performance of genre. And it will be through the means of the image, and its subsequent narratives, that the mark of the tragic fate will be activated. A fact which reveals that the "binary frame for sex and genre are regulatory fictions which reinforce and naturalize the convergent power regimes of masculine and heterosexist oppression." (Butler, 1990, p.99). With this, the didactic role of the myth becomes noticeable and it will be that limitation which will show the action imposed in respect of the behaviour of the physical bodies.

As we follow the historical mutations added to this archetype, we see how the genre insists in intervening in the feminine heroic body. As Hagedorn pointed out "it is possible for a twenty-first-century feminist to view Boccaccio as an important precursor who articulated a coherent vision of woman in history" (2004, p.12). The consecrated work De claris mulieribus (1374) by Boccaccio is a good example of this. In that treatise about famous women, the illustrious women, we perceive that the author builds a catalogue of prominent feminine figures from Classical antiquity with the quality of a manifesto which denounces the slight interest of literature in narrating the life of women as opposed to that of the illustrious man. This book not only presents women who are not saints as examples; it actually focuses on "problematic women" (Kolsky, 2003, p.69). As such, the main point is centered in narrating the relevance of some female facts slightly appreciated throughout history. There are no doubts that the image of these women do crystalize at a certain time, reflecting its own markings. At any rate the book reveals itself as a compilation summarizing the bad female examples in opposition to the good, contributing alterations of a Classical antiquity adapted to a renaissance influence. Penthesilea, as a historical figure, is not forgotten, and the author distorts her by 
adapting the myth, expressing the power of this heroine as love. Boccaccio, in his description of Penthesilea, accepts her as a feminine figure on body, but "non muliebri" (Boccaccio, 1995, p.92), a factor that will allow her constant association with the diurnal elements mentioned earlier. Thus, Boccaccio associates the image of Penthesilea to a diurnal system par excellence, at the same time that he negates her genre. It must be noticed that in this version, love will be the main driving force in the involvement of the heroine in the Trojan war. Very briefly, Penthesilea is in love with Hector, whom she wishes to have a child with, which makes her enlist for the war, two factors never mentioned until now and both unrelated to our baseline. It is interesting to observe that even so, these elements recall the obsessive leitmotiv of the mythical section analysed earlier, the warrior woman that falls in love and fails, despite herein the solar woman finds her strength in love, making everything possible to win it over. We can come to the conclusion that if, at any time her glory is equalled to that of the hero, this romantic factor distances it immediately. That way, by means of the narrative we observe that even though her image merges with a structure of full power, its virtuality reflects a weakness linked to the feminine, a gender mark. The evidence shows that the image of the heroine suffers a rupture; her power, if it exists, is motivated for and with the man, distorting the character of her falling in love within the mytheme, which goes on to occupy a central place within this mythology.

Another derivation of time about the archetype of Penthesilea is found in a theatre piece written by Heinrich Von Kleist in 1808, in which the author introduces traces of drama in this mythical section. Here we verify, once again, the extent to which historical change produces new disguises for the very same archetype. In this case, it is very clear how romanticism intensifies factors that do alter Penthesilea destiny. Narratively there is a big twist in this version; we emphasize the fact that, for the first time, women's victory is allowed. It is Penthesilea who, finally, is provided with a superior solar power, she kills Achilles with her spear, beating the warrior, while is saying: "I'm so happy, sister! With excess! Oh, Diana, I feel so ripe for death! It is true that I do not know what has happened to me here, but I could die with the firm belief that I have defeated the son of Peleus (Achilles)" (Kleist, 2000, p.109). We could say that the myth keeps its nuances in a strength characterized by the diurnal and that the fact that victory finally allows for the rising of femininity. However,

1 Boccaccio, 1995, p. 92: "Hanc aiunt, oris incliti spreto decore et superata mollicie feminei corporis, arma induere maiorum suarum aggressam; et auream cesariem tegere galea ac latus munire faretra, et militari, non muliebri, ritu currus el equos ascendere; seque pre ceteris preteritis reginis mirabilem exhibere, viribus et disciplina, ausa est”. 
her image keeps on reflecting a virtualized weakness, stressed by the distortion of her falling in love; this time, the heroine falls in love at the moment in which she recognizes the possibility of love in the dead body of Achilles. At the end, she will put an end to her life for not being able to live with her own actions. It is possible to see in this suicide another form of punishment which reiterates the weakness of the female, a factor which reintegrates the falling in love as an essential matrix of this archetype, leaving her diurnal/masculine power as a secondary factor of her image.

Laura Mulvey also acknowledges a mythical superdimension inscribed in the history of Penthesilea, and in 1978 she carries out a film with this very name, Penthesilea: Queen of the Amazons, together with Peter Wollen. The unfolding of the myth in a superposition of layers established in it, in which virtual and actual spaces coexist, as well as the use of overlapping feminist discourses with archive images from the women suffrage movement endorse this idea. We extract from this example that Mulvey revives the possibility of a coexistence, within the same image, of the speculative myth and the utopian myth, in such a way that it is possible to state that in the film there is the resurgence Kleist work as an exploration of iconography, history and bodies marked by gender, performing the essence that the myth of Penthesilea evokes. Mulvey suggests to the spectator an immersion through historical rescues, evoking an imaginary world at the same time as a real one. The film questions the nature of the amazon women exposing her essence (were they strong women or, rather, the creation of some masculine fantasy?) Of these questions arise the oppositions between dualist discourses, in which a central message is inscribed to dialectics, which presents the past revealing its traces in the present. Thus we observe how Mulvey uses certain strength of the cinema in order to reveal the crystallization of the myth, dismembering the layers of the different time intervals in the search of a real image. As a synthesis, there is constant evidence that shows the imposition of images (pre-)constructed about a past. It is a film made up of four parts which denounces history as an obstacle, a distortion to be overcome.

This is what is exposed in the process of collage and montage, based on an intense use of fragments of plays, images and classic iconography. The fragments themselves are inserted on stage as a mechanism of resilience and female struggle, a kind of counter-proposal to the historical impositions that the images make on the genre. As a consequence, this juxtaposition invokes a profound questioning of the representations of the bodies. In the third fragment, this becomes particularly visible through a montage of oppositions. Let us take into account, for example, 
the moment when sculptures of the ancient Amazonian warriors are confronted and, a posteriori, we see the corporeal representations of Wonder Woman in the comics, a clash that announces the historical performativity that subsumes the feminine gender. Butler, in her studies, emphasizes that "gender is a performativity produced and classified by the regulation of practices" (Butler, 1990, p.24), and there is no doubt that Mulvey and Wollen propose to denounce such practices through this film, leading the viewer to revise history in order to move towards a reconstruction of the facts.

From this last reference we perceive, in a way, a deployment that leads to the methodological strategies that serve to profile the analysis of this paper. If we admit that the updates of the mythological image of Penthesilea have a double capacity, that is to say, that they are double images in nature and that they derive this duplicity from time, we can see, from Mulvey's film, some mechanisms that incorporate layers and add new meanings to a mythical image, a clear manifestation of that crystal that exists in every archetype. Let us take into account Deleuze's reflection, which admits that "cinema does not only present images, it envelops them with a world" (Deleuze, 2013, p.87), affirming that the derivations of time in cinema add new layers to images. And with this, a peculiar capacity of cinema comes, to expose times that coexist; present and past, virtual and real is revealed. We reiterate that, in this way, we reflect on this mythological image and its updates in the cinema, referring to the idea of Deleuzian image, which designs a kind of a "point of indiscernibility between two different images, the present and the virtual" (Deleuze, 2013, p. 87).

\section{ABOUT THE MUTATIONS}

In the epic, the etymology of the word Kleos refers to a glorious death. Thus, when the muses chanted the great heroic deeds, they did nothing but invoke Kleos, eternalizing its splendors in song lyrics. That is to say, these deaths were not in vain, because finally the great heroes found their place in the much desired eternity. Meanwhile, it is revealing to note that the feminization of the word is non-existent: there are no songs that refer to a Kleos Gyne. As a matter of fact, it is a constant: female deaths were not worthy of the glorious honors in Ancient Greece. If we refer to this, it is due to the fact that, within the various updates of the myth of Penthesilea and her experience of death in battle, one could enunciate an honour that called for the celebration of a kind of 'Kleos Gyne'. Having said this, we would like to emphasise that we perceive a 
distorted feminine glory in the Pentesilean narrative and pictorial motif. From this point of view, we can see, in the continual updating of Penthesilea, signs of a constant changing and exposing a struggle.

Without doubt, this gap is being sutured in the contemporary world. If we take into account the current scenario, it is interesting that this limitation can be extended to a large number of heroines. It should come as no surprise that other well-known names, such as Diana (Wonder Woman, Jenkins, 2017), Katniss (The hunger games, Ross 2012), Elektra (Elektra, Bowman, 2005 and Daredevil, Johnson, 2003), or Catwoman (Catwoman, Pitof 2004) are announced as an open representation of the new forms of female protagonist. In this sense, we perceive a similarity between so many chords of different voices: their mutations, insofar as they are related to the structures of the imaginary, mask a struggle against the transhistorical imposition of the representation of female power. It is clear that the transformations that regulate the dispute between the genders are beginning to be incorporated into the construction of these protagonists. They are alterations that, evidently, connect with social changes. As a result, we witness new discursivities that allow a kind of unblocking of the image. In the end, we witness the birth of a series of heroines who demonstrate in their representative bodies attempts to ascend figuratively.

As an example, we can quote Star Wars: Ep. VIII The Last Jedi (Johnson, 2017), a clear exponent of the new ascensional impulse that the contemporary heroine is experiencing, a film in which a humble scrap dealer manages to master the art of the Jedi sword, a weapon that is "the culmination of the reconciliation of the epic -sword- with the transcendent light" (Bou y Pérez, 2000, p.87). Similarly, we could mention the nostalgic reboot of Tomb Raider (Uthaug, 2018). In it we meet again a young Lara Croft outlining her first steps towards a diurnal regime, so that the symbolic ascent is represented de facto when the heroine, after the sacrifice of her father, ascends to the light. And it is literal: Lara has descended into an underground tomb and finds herself hanging over the abyss when the rocks start to collapse, the ceiling collapses and the climbing mechanism is activated to retract the rope. As the rocks fall, Lara's body ascends to the surface gap, where the sun shines. Like an umbilical cord stretched by the star itself, Lara Croft will be born on her way through a stone womb, named after a solar ascent. It is curious that in these two examples there is a clear confrontation that insists on returning to tighten the two poles of heroism between the feminine and the masculine. Hence, the importance of Lara contradicting her father or King confronting Kylo. From these two confrontations it is even more revealing to observe how the masculine and the feminine have their equal forces. 
Agamben, asking about the meaning of "being contemporary", ends up revealing that this answer is found in a proximity to "the origin that beats in the present" (Agamben, 2011, p.6). At the same time "the origin is not only situated in a chronological past: it is contemporary with the historical becoming and does not cease to operate in it" (ibid.). And, precisely, to be contemporary is to act on this incessant deviation, to reinsert the deviation towards the origin, accompanying it in an ambiguous proximity andsimultaneously, revealing an unreachable anachronism. In the end, the contemporary subject is configured as an alloy between the "unlived and in everything lived", which implies a special relationship between the times.

In this way, it seems clear to us, we have underlined a narrative and figurative insistence that strives to overcome a moment in the past. And it is precisely from this operation that we have seen how a trauma, seen in the insistence of the feminine diurnal power and its respective love toll, becomes transmuted into the present. It gives a very precise image of the meaning of being contemporary proposed by Agamben.

Even so, in this first analysis, certain nuances become evident which reveal a slow evolutionary curve of some of the representations of the feminine symbolic power. Therefore, it is necessary to return to the image with which we started this research and to remember that we are in a universe in which the fall of Penthesilea is the signal that prefigures our whole journey. If we pay attention to these points, we are not very far from a curious dependence on the figure of the male that would go back to the hurtful hand of Achilles. Thus, redoing these trajectories, we can see without a doubt that all the heroines up to this point carry a mark of dependence towards the male element. However, this female dependence on the "legitimate hero" must be overcome, a recurrence that reinforces our hypothesis of the need for a love toll that the heroines must compensate for in order to access the much-desired daytime ascent.

Between 2003 and 2004, Tarantino also evoked feminine power from the images with Kill Bill [here we are quoting the two volumes of the saga] and some peculiarities of Wuxia art, with western derivations. The director gives body to a warrior through a visual device that narrates the journey of a revenge as the only way of redemption. Let us therefore take a close look at some of the elements involved in the symbolic contrast between the two regimes of the image.

The protagonist, without a name, connects perfectly with this symbolic device, developing its bases in the diurnal regime, that is to say, in the movement and action, an idea that also is vectored in its physical aspect, by its golden hair and its yellow clothes. In opposition, we observe, 
in Vol. 2, a return journey home that has "a deep structure of melodrama" (Benavente, 2017, p. 54). In this new stage of the journey, multiple formulations appear that point to a change of regime, such as the temporal flow of the film that passes to value more the words and memory, evoking shades typical of twilight westerns. In Benavente's words, we move "from the engine of revenge to the need for legacy" (ibid.). Therefore, it is not surprising to see how, in this second film, the narrative is structured around a new opportunity which allows the protagonist to re-inhabit her nightlife.

From this point of view, it is curious to observe how, in this new structure of images unusual for a protagonist marked by the day until then, we observe in the confrontation of her and her archenemy a defeat so easy that it comes close to a caricature. This failure is nuanced by the tonality of twilight, under which something different will soon manifest itself in the path of this heroine, once word and memory return to the narrative centre of her story. Thus, after a long flashback, we find ourselves with a sequence that constitutes itself as a micro-representation of the fall of the heroine. It is a moment that culminates in the loss of her sword, her solar weapon. After this journey of rupture, structured in a collapse, the character of Uma Thurman will be buried alive to literally be reborn in her daytime. Thus, we finally meet Beatrix Kiddo, a rebellious solar heroine, who with her agile essence sustains an emotional fury, defeating death to finally go in search of redemption.

Above all, we think it's important to stress that the way the film's plot has developed will allow this protagonist to also revive the mythical essence of Penthesileia, by embodying a woman who enters into battle to challenge the powerful dominions of man. If we look at the visual indexes, we find once again, how the elements point to a kind of archetypal remembrance that insists on returning. This discourse organizes, mainly in the second volume, a sort of epic-tragic resurgence of our capital image. Here, death is configured as the only currency of exchange, just as love becomes a constant of violence and struggle for power. Thus, the key that reinforces this idea is present, above all, in Beatrix and Bill's relationship. As we saw in the previous pages, the mythical is marked by the repetition of a form of infatuation, where all the lines culminate in a failure that crystallizes ultimately. We can affirm that in this case we also observe the same matrix which insists on tensioning two opposites that attract each other and lead them towards a loving confrontation. We should not overlook, however, the fact that in this example Beatrix Kiddo's irrepressible desire for revenge appears as an absolute background. This entails a reversal of the pattern of male superiority, according to which anger is config- 
ured as a central point, revealing that "the fury of vengeful women demonstrates a strength superior to that of the outmoded male power" (Bou y Pérez, 2010, p.56).

Leaving aside the plot structures and focusing on the exact configuration of this image that reflects a symbolic moment, it will be in the final scene of the film where a sort of superposition of layers will be revealed, accumulated from a past that claims its presence in the image. In this way, in the frenzy of the long-awaited meeting between Beatrix and Bill we see signs that immediately point to the pictorial staging with which we open this investigation, taking into account the reducible structure of the symbolic implications of Penthesilea and Achilles. In the meeting between Beatrix and Bill we once again appreciate the return of the ephemeral moment of penetration into the chest and the exchange of glances between the protagonists, underlined by a perfect unity in this mise en scène. If we have in perspective that the visual contact is used as a key formal procedure to reveal the passion between these two characters, it is not surprising that in this sequence the use of the shot and the reverse shot rescues the essence of an "approximating mechanism between the protagonists" (Bou, 2002, p.56) ${ }^{1}$. However, as opposed to what would be considered a classic structure, we observe that the general shots barely condense the tension, without presenting at any moment the long-awaited amorous encounter between the characters. In fact, the general planes illustrate the reverse side of the desire, providing only the confrontation between these opposites. Thus, we observe a constant and obsessive double game of tension versus attraction that culminates in the moment when Beatrix kills Bill by touching his heart with the "five-point-palm-breaking".

It seems obvious to us that Beatrix's symbolic penetration of Bill's chest is the ghostly appearance of a precise image, but at the same time it inverts and deforms Achilles' gesture. We note one detail: if at our starting point the difference in power is represented by the corporeal position, in this scene, on the contrary, it is cancelled out. There is an equality of power between the protagonists, who in turn are presented in the scene seated, without anybody protruding above the other. This fact implicitly indicates that the two are equal parts of an equable confrontation. The importance of this detail becomes even more evident when we recognize that it is the solar woman who will have the opportunity to win in this battle. While this positional transformation figures the obvious, the structural self-awareness of the archetype, the element of penetration appears

1 In the third chapter of the book, Bou points out in detail the mechanisms of representation of passion in classical cinema. One of the points addressed touches on the contraposition of the planes of the characters that are looked at and the structures that condense the tension of falling in love. 
in a simple gesture that paralyzes the hero, materialized in a (martial) touch of the heart. And, precisely at the limit of the beam of light coming from the twilight environment, the figure of the solar man will be defeated, in a scene that closes with a walk, a minuscule pilgrimage of the hero that, finally, collapses before the night.

So, in that sequence, something would be shaping up as a true alchemy of time. The projection of a past archetype becomes present, it becomes material and flesh. Penthesilea returns here with the immediacy of the mythical schemes, whose continuity does not end in history. And the fact is that to enunciate this maxim confirms that every image has a history capable of transcending time, an idea that brings us closer to Benjamin when he speaks of "the manifestation of a remoteness, however close it may be" ( Benjamin, 2003, p. 47). The Benjaminian dictum would also serve to think about the image of Penthesilea, whose symbolic depth imprints a remoteness that returns and re-enters the closeness of its manifestations, to reach each time the present of its time.

In spite of the importance of this iconic investment synthesized in the feminine victory, it is fundamental to emphasize that Bill appears narratively as the great manipulator of power. After all, he has access to a part that was torn from Beatrix's character, which, not by chance, appears as a being who has been through a fault, which becomes concrete at the end of the film, in the figure of a mother without a child. The entire symbolic investment therefore stands in contrast to a basic truth: the male element is the knower and controller of a part of the heroine. The absolute power of this heroine's destiny is again in the hands of her male counterpart. It is this male figure that, in the end, closes the fight and grants symbolic redemption, although it is true that this detail does not annul the ascension of the female power. It seems, therefore, that the woman is authorized to transit between one regime of image and another, being able to figure as mother and warrior at the same time. That's why the final shot of the film, more specifically Beatrix's cry, is a sign of women's victory. However, she was conquered with what would be the coins of a historical toll, duly collected respecting the rules pre-written by the mythical structure of Penthesilea.

Of all the films that make up this struggle of the feminine to conquer a luminous ascent in the contemporary world, it is the peculiar adventure of Furious in Mad Max, Fury Road (Miller, 2015) that provides one of the most unforgettable expressions of a new figuration of diurnal power. Without a doubt, George Miller, in this last instalment, has constructed a film that values the power of images, a factor that intensifies the possibilities of a reading from a symbolic imaginary. Therefore, starting from the 
ephemeral moment of Penthesilea's defeat until reaching the elevation of Furious, in the final shot of this film, we perceive what could be described as a structural change, which we will call, for now, the heroine's journey. This fact is further enhanced by the withdrawal of the male protagonist from the scene. In this sequence marked by a distant gesture of farewell between hero and heroine, we see possible signs of new nuances culminating in the overcoming of female power as opposed to male power. This idea is also present in the visual narrative, as we distinguish a kind of dualistic tension that divides a post-apocalyptic world into two facets.

Let's take into account the use of blue and orange filters that divide the scenarios of this dystopia, indexes that suggest duality, a possible association to the same type of tints that, for example, Murnau and other authors of silent films used to configure an expressionism of the day and night. It should be noted that orange tones predominate in this film, a clear suggestion that its core lies in the diurnal regime, leaving the nocturnal in the background. In this combination perfectly synthesized by the play of color, there lies the model example of a strategy that prioritizes those images connected to a hegemony of the solar. Thus, based on what we have pointed out so far, we could say that one of the dramatic structures of the action lies in the idea of an inversion of the roles of the protagonists and their respective regimes of associated images. Thus, in this disjunctive we can see the figuration of a nocturnal hero, Max, and a solar heroine, Furious.

From this knot tightened from different ends we approach the protagonist and her search for redemption: Empress Furious, an apocalyptic Amazon who tames time with her war vehicle. According to Durand, "the horse is a symbol of the flight of time" (Durand, 2012, p. 78), and, as a consequence, when the hero is capable of dominating it, he is demonstrating a superiority over the future. In this dystopia we perceive the full consummation of this idea since horses are replaced by the movements of cars and motorbikes, leaving no doubt that Furious controls speed and time with great skill.

Under this point of view, it is curious to observe how we witness a figure backed by a corpus of images that embodies the refraction of a struggle of the feminine to inhabit a regime that was historically denied to her. In fact, there is a game of conflicts in its representation: deformed heroine, with her body amputated and her head naked, signs that make way for symbolism to take shape in figurative absences. In Durand's words: "hair is not connected to water because it is feminine" but, "on the contrary, it is feminized because it is the symbol of water, (...) because it is at the same time a microcosmic symbol of the wave and technologically 
the natural thread that serves to weave the first knots" (Durand, 2012, p. 107). In this image of an amputated heroine, without the presence of typical hair associated with the feminine, there is an imposition of diurnality on this solar heroine. However, the device goes even further, if we take into account that one of the fundamental motives that will set the tone of the narrative development is centred on the struggle for the control and liberation of water. So, if the figurations of water in a symbolic imaginary refer again and again to a germinal feminization, then we can affirm that the proposed narrative itinerary enunciates an approach that revolves around the struggle for the liberation of the feminine.

By articulating this schematic operation we could establish a link between Furious and some Pentesilean shades. However, as we pointed out at the beginning, "the crystal reveals a direct time-image" (Deleuze, 2013, p. 121), unmasking the concealment of time, allowing the image to show its polychiefalism and dismantle its facets. This is perceived in the power of a returning image, during the sequence that relates the near-death experience of Furious. It is from this moment that we perceive an exact pictorial recreation of the gesture of the hero's penetration into the heroine's body. If we start from the confrontation between Achilles and Penthesilea in which the hero kills her, we perceive that past and present again coexist in an image when Max, in order to save Furious, has to reproduce the same gesture as Achilles. But in this case, the act is updated, and, in opposition, the hero asks forgiveness for the wound he is producing, cancelling out the brutality of piercing the female body: an image that perfectly engages a symbolic device. This penetration, both physical and metaphorical, provides the key to a time that unfolds from a gesture. As if the penetration of the knife had transported us to a ray of light that wanders through history, retaining within itself all the intensity of a gesture. This spark links the representation of violence, from a past that, on being updated in the present, is substituted by an act of salvation. Therefore, it is from this double itinerary of the image that Penthesilea and Furious live together on the same symbolic scene. And it is in the image that emerges between the past and the present that the echo of the feminine in its struggle to access diurnality is manifested.

In the previous pages we have observed that the mythical section of Penthesilea reveals a constant that implies a form of infatuation. Let us review, then, some of the elements that come into play in the following scenes. Max, after the act of salvation, experiences a moment of intimacy with Furious, finally revealing her name, the mark of her identity; a scene that leaves in suspense the idea of a possible passionate approach between the two characters. In this sequence, we perceive a return of stabil- 
ity to the shot, based on shared gazes used in a shot-reverse shot structure, a mechanism that, while highlighting a passionate approach between the characters, reactivates nuances present in our traumatic image. Nevertheless, Furious is dependent on whoever appears as the legitimate male hero. As we observe in the continuity of this scene, she needs his blood to survive, being only from the moment of the blood transfusion between these two characters that the heroine has the opportunity of a possible female ascension - as if the female body had to receive the appropriate blood to be reborn in the diurnal regime.

Finally, we return to the scene with which we started, when the solar heroine rises to power, while the water is finally released and the hero withdraws from the picture. But, as we have emphasized, she has had to be reborn with male blood in order to enjoy the much-desired diurnal regime. So Furious revives the essence of Penthesilea, showing that her image does not disappear; as long as there are women who know the bitterness of defeat for inhabiting a regime that does not belong to them, the signs of this invisible warrior will remain.

After observing these female bodies in action, we must infer that we are faced with a range of heroines who present a break, or rather a change of pattern. What do their images portray? We find ourselves before an enclave, a crossroads where, among heroines belonging to different scenes, a common feature becomes visible referring to a turn that imprints again and again the traces of a tragic past. We find departures from the image that grant a kind of celebration of a late feminine victory, which would emerge in favour of a form of ascension and its respective unblocking in the face of a diurnal regime of the image. So, by questioning these images in their respective particularities, we perceive in the journey of Furious and Beatrix a settlement of solar fullness as opposed to a limitation imposed by the trauma of Penthesilea's wound. Even so, we have insisted on this moment in the past that is made in the present, marked by an iconographic return that insists on returning to each attempt at female ascension.

\section{FINAL CONSIDERATIONS}

Once these nuances have been explained, we could say that Penthesilea bears the mark of an essentially solar/diurnal heroism, in which love will configure as an additional item that makes the characters confront each other violently. This ends in heterosexual relation. Having said that, we have already examined certain constants which confirm that "man and woman are concepts of political opposition" (Witting, 2006, p.53). As a 
consequence, we have proved that a heterosexual thought is configured as the main factor to impose falling in love between the characters, condemning the feminine to the defeat. Penthesilea not only reveals what is the space that must be occupied by a body that bears the mark of the feminine, but also shows us what is the role that must be played by the masculine in our society.

We have decided to turn to a mythical figure not in order to find a possible origin, but rather to discern its presence. We recognize that "beyond any apparent beginning, there is always a secret origin - so secret and so fundamental that it can never be quite grasped in itself" (Foucault, 2010, p. 38). As Deleuze rightly said, "the dead spots on the map would have to be reset" (2002, p. 19) to finally open them up to possible lines of escape. And it will precisely be the search of its historical roots, and its possible resurgences where we will discover the repetitions, or better, the deformations of the force related with the duality of genres. At in this juncture, we could state that from this double character of the image, tightened over the projection of the present and the past, the singular archaeology of a fight becomes visible. However, we must be aware that the said idea has already been indicated since the absence of celebration of a Klea Gyne ${ }^{1}$, before Virgil mentioned for the first time the defeat of Penthesilea, or the first artist printed the stain of her collapse. Without a doubt, we find ourselves before a history which insists to be once told once again, although nobody knows the origin of its first words. With this we maintain that the image of arising feminine power reveals a common blockage that very possibly goes beyond our basis. Nevertheless, this paper, until now, has shown a constant: Penthesilea has fought to arise over the main obstacle, the mark of her gender.

\section{References}

Agamben, G. (2011). “Qué es ser contemporáneo?” ["What is it to be contemporary?"]. En Agamben, G., Desnudez. Buenos Aires, Argentina: Adriana Hidalgo. [Ensayo original publicado en 2007 a partir del curso de filosofía que Giorgio Agamben dictó en el Instituto Universitario de Arquitectura de Venecia - Original essay published in 2007 from the philosophy course that Giorgio Agamben taught at the University Institute of Architecture of Venice]. (in Spanish)

Benavente, F. (2017). El héroe trágico en el western. El género y sus límites [The tragic hero in the western. Gender and its limits]. Sevilla, España: Athenaica. (in Spanish)

1 In reference to the famous celebrations of heroic events known as Klea Andron. 
Benjamin, W. (2003). La obra de arte en la época de su reproductibilidad técnica [The work of art at the time of its technical reproducibility]. México DF, México: Ed. Itaca. (in Spanish)

Boccaccio, G. (1995). De claris mulieribus: Die grossen Frauen [De claris mulieribus: The great women]. Stuttgart, Alemania: Reclam. (in German)

Bou, N. \& Pérez, X. (2000). El tiempo del héroe. Épica y masculinidad en el cine de Hollywood [The time of the hero. Epic and masculinity in Hollywood cinema]. Barcelona, España: Paidós Ibérica. (in Spanish)

Bou, N. (2002). Plano y contraplano de la mirada clásica al universo de Michelangelo Antonioni [Plane and backplane of the classic look at the universe of Michelangelo Antonioni]. Madrid, España: Biblioteca Nueva. (in Spanish)

Bou, N. (2006). Diosas y tumbas. Mitos femeninos en el cine de Hollywood [Goddesses and graves. Female myths in Hollywood cinema.]. Barcelona, España: Icaria Editorial. (in Spanish)

Bourdieu, P. (2009). La dominación masculine [Male domination]. Barcelona, España: Anagrama. (in Spanish)

Braidotti, R. (2000). Sujetos Nómades [Nomadic subjects]. Buenos Aires, Argentina: Paidos. (in Spanish)

Butler, J. (1990). Gender Trouble. Feminism and the subversion of identity. New York, EEUU: Routledge.

De Esmirna, Q. (2004). Posthoméricas [Posthomerics]. Madrid, España: Editorial Gredos.

Deleuze, G. \& Guattari, F. (2002). Mil mesetas. Capitalismo y esquizofrenia [A thousand plateaus. Capitalism and schizophrenia]. Valencia, España: Pre-Textos. (in Spanish)

Deleuze, G. (2013). A imagem-tempo [The time-image]. São Paulo, Brasil: Brasiliense. (in Spanish)

Durand, G. (1993). De la mitocrítica al mitoanálisis : figuras míticas y aspectos de la obra [From myth criticism to myth analysis: mythical figures and aspects of the work.]. Barcelona, España: Anthropos Editorial del Hombre. (in Spanish)

Durand, G. (2000). Lo imaginario [The imaginary]. Barcelona, España: Ediciones del Bronce. (in Spanish)

Durand, G. (2012). As estruturas antropológicas do imaginário: introdução geral [Anthropological structures of the imaginary: general introduction.]. São Paulo, Brasil: Martins Fontes. (in Portuguese)

Foucault, M. (2009). La arqueología del saber [The archeology of knowledge]. México DF, México: Siglo XXI. (in Spanish)

Hagedorn, S. (2004). Abandoned women: rewriting the classics in Dante, Boccaccio, and Chaucer. Michigan, EEUU: University of Michigan Press.

Kleist, H. (2000). Pentesilea. Barcelona, España: Diputació de Barcelona. (in Spanish) 
Kolsky, S. (2003). The genealogy of women: studies in Boccaccio's De Mulieribus Claris. New York, EEUU: Peter Lang Publishing.

Mulvey, L. (2013). Penthesilea and Riddles of the Sphinx. Disponible en el libro que acompaña el DVD BFIVD982. Londres, Reino Unido: BFI.

Noel, J. F. M. (1991). Diccionario de Mitologia Universal. Tomo 2 [Dictionary of Universal Mythology. Volume 2]. Barcelona, España: Edicomunicación. (in Spanish)

Rich, A. (1979). On lies, secrets, silence. New York: W. W. Norton.

Virgili. (2005). L'eneida. Barcelona, España: Bolsillo/Butxaca. (in Spanish)

Witting. (2006). El pensamiento heterosexual y otros ensayos [Heterosexual thinking and other essays]. Barcelona, España: Eagles. (in Spanish)

\section{Список литературы}

Agamben, G. (2011). “Qué es ser contemporáneo?” ["What is it to be contemporary?"]. En Agamben, G., Desnudez. Buenos Aires, Argentina: Adriana Hidalgo. [Ensayo original publicado en 2007 a partir del curso de filosofía que Giorgio Agamben dictó en el Instituto Universitario de Arquitectura de Venecia - Original essay published in 2007 from the philosophy course that Giorgio Agamben taught at the University Institute of Architecture of Venice]. (in Spanish)

Benavente, F. (2017). El héroe trágico en el western. El género y sus límites [The tragic hero in the western. Gender and its limits]. Sevilla, España: Athenaica. (in Spanish)

Benjamin, W. (2003). La obra de arte en la época de su reproductibilidad técnica [The work of art at the time of its technical reproducibility]. México DF, México: Ed. Itaca. (in Spanish)

Boccaccio, G. (1995). De claris mulieribus: Die grossen Frauen [De claris mulieribus: The great women]. Stuttgart, Alemania: Reclam. (in German)

Bou, N. \& Pérez, X. (2000). El tiempo del héroe. Épica y masculinidad en el cine de Hollywood [The time of the hero. Epic and masculinity in Hollywood cinema]. Barcelona, España: Paidós Ibérica. (in Spanish)

Bou, N. (2002). Plano y contraplano de la mirada clásica al universo de Michelangelo Antonioni [Plane and backplane of the classic look at the universe of Michelangelo Antonioni]. Madrid, España: Biblioteca Nueva. (in Spanish)

Bou, N. (2006). Diosas y tumbas. Mitos femeninos en el cine de Hollywood [Goddesses and graves. Female myths in Hollywood cinema.]. Barcelona, España: Icaria Editorial. (in Spanish)

Bourdieu, P. (2009). La dominación masculine [Male domination]. Barcelona, España: Anagrama. (in Spanish)

Braidotti, R. (2000). Sujetos Nómades [Nomadic subjects]. Buenos Aires, Argentina: Paidos. (in Spanish) 
Butler, J. (1990). Gender Trouble. Feminism and the subversion of identity. New York, EEUU: Routledge.

De Esmirna, Q. (2004). Posthoméricas [Posthomerics]. Madrid, España: Editorial Gredos.

Deleuze, G. \& Guattari, F. (2002). Mil mesetas. Capitalismo y esquizofrenia [A thousand plateaus. Capitalism and schizophrenia]. Valencia, España: Pre-Textos. (in Spanish)

Deleuze, G. (2013). A imagem-tempo [The time-image]. São Paulo, Brasil: Brasiliense. (in Spanish)

Durand, G. (1993). De la mitocrítica al mitoanálisis : figuras míticas y aspectos de la obra [From myth criticism to myth analysis: mythical figures and aspects of the work.] Barcelona, España: Anthropos Editorial del Hombre. (in Spanish)

Durand, G. (2000). Lo imaginario [The imaginary]. Barcelona, España: Ediciones del Bronce. (in Spanish)

Durand, G. (2012). As estruturas antropológicas do imaginário: introdução geral [Anthropological structures of the imaginary: general introduction.]. São Paulo, Brasil: Martins Fontes. (in Portuguese)

Foucault, M. (2009). La arqueología del saber [The archeology of knowledge]. México DF, México: Siglo XXI. (in Spanish)

Hagedorn, S. (2004). Abandoned women: rewriting the classics in Dante, Boccaccio, and Chaucer. Michigan, EEUU: University of Michigan Press.

Kleist, H. (2000). Pentesilea. Barcelona, España: Diputació de Barcelona. (in Spanish)

Kolsky, S. (2003). The genealogy of women: studies in Boccaccio's De Mulieribus Claris. New York, EEUU: Peter Lang Publishing.

Mulvey, L. (2013). Penthesilea and Riddles of the Sphinx. Disponible en el libro que acompaña el DVD BFIVD982. Londres, Reino Unido: BFI.

Noel, J. F. M. (1991). Diccionario de Mitologia Universal. Tomo 2 [Dictionary of Universal Mythology. Volume 2]. Barcelona, España: Edicomunicación. (in Spanish)

Rich, A. (1979). On lies, secrets, silence. New York: W. W. Norton.

Virgili. (2005). L’eneida. Barcelona, España: Bolsillo/Butxaca. (in Spanish)

Witting. (2006). El pensamiento heterosexual y otros ensayos [Heterosexual thinking and other essays]. Barcelona, España: Eagles. (in Spanish) 